\title{
CHARACTERIZATION OF RESERVOIR ROCKS AND FLUIDS BY SURFACE ELECTROMAGNETIC TRANSIENT METHODS
}

\author{
Quarterly Report for the Period \\ April-June 1991 \\ By \\ Pieter Hoekstra

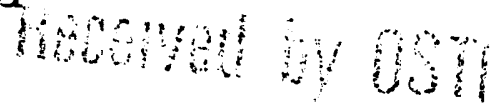 \\ NOV.1\%8 1991
}

Work Performed Under Contract No. AC22-90BC14476

\author{
R. E. Lemmon, Project Manager \\ Bartlesville Project office \\ P. O. Box 1398 \\ Bartlesville, OK 74005 \\ Prepared by \\ Blackhawk Geosciences, Inc. \\ 17301 w. Colfax, Suite 170 \\ Golden, CO 80401
}

\section{DISCLAIMER}

\begin{abstract}
This report was prepared as an account of work sponsored by an agency of the United States Government. Neither the United States Government nor any agency thereof, nor any of their employees, makes any warranty, express or implied, or assumes any legal liability or responsibility for the accuracy, completeness, or usefulness of any information, apparatus, product, or process disclosed, or represents that its use would not infringe privately owned rights. Reference herein to any specific commercial product, process, or service by trade name, trademark, manufacturer, or otherwise does not necessarily constitute or imply its endorsement, recommendation, or favoring by the United States Government or any agency thereof. The views and opinions of authors expressed herein do not necessarily state or reflect those of the United States Government or any agency thereof.
\end{abstract}


QUARTERLY PROGRESS REPORTS

Blackhawk Geosciences, Inc.

17301 West Colfax, Suite 170

DOE Contract No.: DE-AC22-90BC14476

Golden, CO 80401

Period Covered: 03/30/91 - 06/28/91

$\star * \star U . S$. Department of Energy Patent Clearance Not Required

Prior to Publication of this Document*\#

Title: Characterization of Reservoir Rocks and Fluids by

Surface Electromagnetic Transient Methods

A thorough analysis of the high TDEM data set acquired over the Basin and Range structure near Elko, NV was nearly completed during this quarter. Two extended abstracts about the results and conclusions derived from an analysis were submitted for presentation at the 1991 Annual Meet: ng of the Society of Exploration Geophysicists in the fall.

Since the main objective of the R\&D under this program are practical algorithms and interpretation procedures for analysis of TDEM data over strong 2-D structures, a detailed evaluation of the applications and limitations of 1-D interpretations must first be made to closely recognize which deficiencies must subsequently be corrected by $2-D$ and $3-D$ analysis. The conclusions from that analysis can be summarized as follows:

(1) 1-D analysis of data over 2-D structures, using non-grounded loop sources as transmitters, shows that meaningful information about the structure can be derived. The location of the structure is approximately positioned correctly, and at distances from the structure comparable to the exploration depth, geoelectric sections are derived that match drill hole information. A "phantom" resistivity layer arises in 1-D inversions for which there is no physical evidence in drill holes.

1-D analysis of data over the 2-D structure using grounded line sources as transmitters show that no meaningful information can be derived from sch data sets.

(3) It is not common in present practices to record horizontal magnetic fields. Horizontal fields were measured in this data set, and an analysis of these data show that they contain important information about the location and depth of occurrence of the structure. 

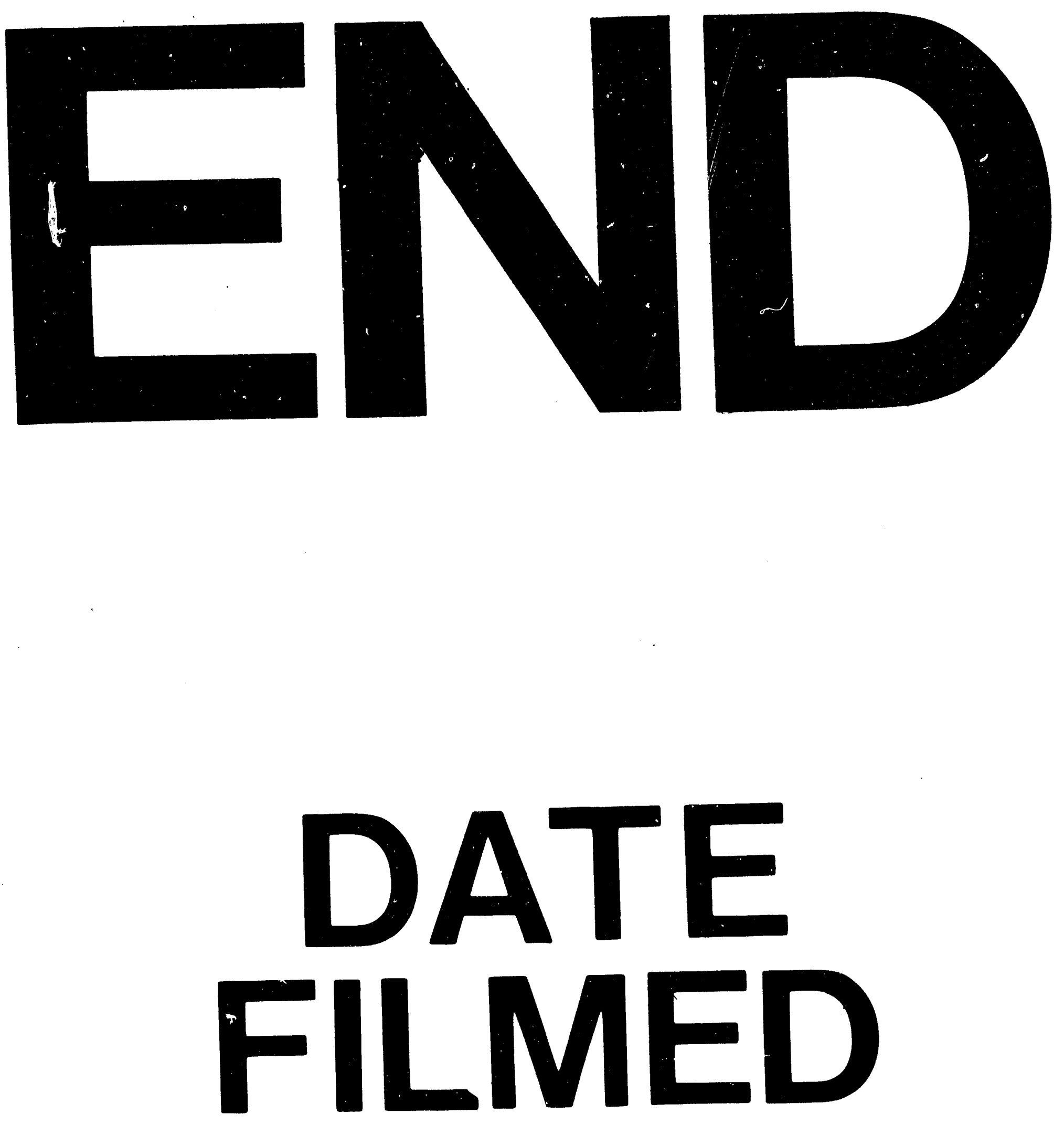

$\uparrow$

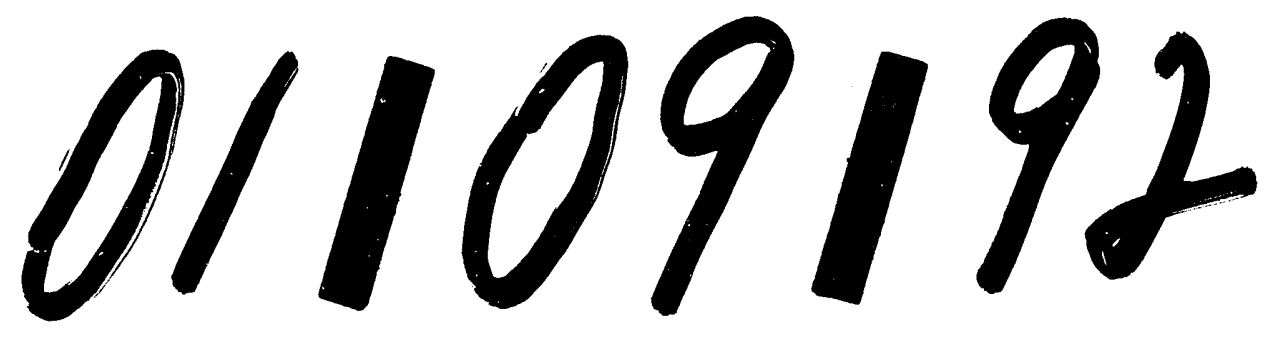


